Youatt, J. B. (1954). J. gen. Microbiol. 11, 139-149.

\title{
Studies on the Metabolism of Thiobacillus thiocyanoxidans
}

\author{
BY JEAN B. YOUATT* \\ The Department of Biochemistry, The University of Leeds
}

SUMMARY: The investigation of the metabolism of thiocyanate by pure cultures of Thiobacillus thiocyanoxidans was complicated by the fact that thiocyanate serves both as source of energy and as source of carbon and nitrogen. It was, therefore, difficult to separate oxidation from carbon dioxide fixation. The equation which best represented the resultant of these two processes was:

$$
2 \mathrm{KCNS}+5 \mathrm{H}_{2} \mathrm{O}+3 \mathrm{O}_{2}=\mathrm{K}_{2} \mathrm{SO}_{4}+\left(\mathrm{NH}_{4}\right)_{2} \mathrm{SO}_{4}+\mathrm{CO}_{2}+\left(\mathrm{CH}_{2} \mathrm{O}\right) \text {. }
$$

Thiocyanate was first hydrolysed to cyanate and sulphide. Cyanate was further hydrolysed to carbon dioxide and ammonia and sulphide was oxidized to sulphate. The oxidation of sulphide approximated to the equation: $\mathrm{Na}_{2} \mathrm{~S}+2 \mathrm{O}_{2}=\mathrm{Na}_{2} \mathrm{SO}_{4}$. Gas uptakes were lower than would be expected from this equation, although special precautions were taken to prevent loss of sulphide.

Thiosulphate was oxidized to sulphate according to the equation:

$$
\mathrm{Na}_{2} \mathrm{~S}_{2} \mathrm{O}_{3}+\mathrm{H}_{2} \mathrm{O}+2 \mathrm{O}_{2}=\mathrm{Na}_{2} \mathrm{SO}_{4}+\mathrm{H}_{2} \mathrm{SO}_{4} \text {. }
$$

Fixation of carbon dioxide after the oxidation of thiosulphate was shown, but the efficiency of energy utilization appeared lower than during the oxidation of thiocyanate.

Thioacetamide and thioacetic acid were oxidized to sulphate but this was believed to be preceded by a chemical breakdown to sulphide. Sulphite, metabisulphite, dithionite, dithionate, tetrathionate, trithionate, thiourea and cysteine were tested; no evidence was obtained of their utilization.

The presence of thiocyanate in gas works liquors led to early experiments on the biological oxidation of the compound. Sludges were activated by exposure to the compound until they were metabolizing 400 p.p.m. thiocyanate ion/ $24 \mathrm{hr}$. The products, ammonia and sulphate, appeared in amounts which suggested the equation: $\mathrm{NH}_{4} \mathrm{CNS}+2 \mathrm{H}_{2} \mathrm{O}+2 \mathrm{O}_{2}=\left(\mathrm{NH}_{4}\right)_{2} \mathrm{SO}_{4}+\mathrm{CO}_{2}$ for the reaction . A preliminary examination of the activated sludge showed the presence of many apparently autotrophic organisms, and it was suggested that the oxidation of thiocyanate supplied energy for autotrophic growth (Happold \& Key, 1934). Further investigations of the bacterial flora were described by Happold \& Key (1937). The autotroph was not isolated in pure culture until 1951 (Happold, Johnstone \& Rogers, 1952); later it was re-isolated and its bacteriological characteristics described (Happold, Johnstone, Rogers \& Youatt, 1954). Gleen (1949) studied thiocyanate metabolism by a soil-perfusion technique. No experimental details were published but he recorded that the same population could use thiosulphate and thiocyanate. He confirmed the production of ammonia and sulphate and suggested the preliminary hydrolysis of thiocyanate to cyanate and hydrosulphide. The aim of the present investigation

* Present address: The Institute for Medical Research, Kuala Lumpur, Malaya. 
was to examine further the metabolism of thiocyanate by pure cultures. Experiments with growing cultures were described by Happold et al. (1954); the present account is of experiments made with washed suspensions of organisms from pure cultures.

\section{METHODS}

Growth and preparation of Thiobacillus thiocyanoxidans. The growth medium contained: $\mathrm{Na}_{2} \mathrm{HPO}_{4}, 1 \cdot 0$ g.; $\mathrm{KH}_{2} \mathrm{PO}_{4}, 0.6 \mathrm{~g}$.; KCNS, $0 \cdot 2$ g.; $\mathrm{MgSO}_{4} 7 \mathrm{H}_{2} \mathrm{O}$, $0.02 \mathrm{~g}$; ; a trace of iron; distilled water to $1 \mathrm{l}$; $\mathrm{pH}$ value between $\mathrm{pH} 7.0$ and 7.2. Thirty to eighty litres were inoculated and incubated at $30^{\circ}$ for $2-4$ days. In a previous paper (Happold et al. 1954) the difficulty of estimating the degree of bacterial growth was described. This was due to the poor growth, the clumping of cells and the variable presence of sulphur particles. Generally, however, the cultures obtained after 2-4 days of incubation showed more than $90 \%$ light transmission, measured with a Unicam D.G. Spectrophotometer in $\frac{1}{2}$ in. tubes at $6500 \mathrm{~A}$. The organisms were harvested in a heat-sterilized De Laval Centrifugal Separator, and after harvesting were washed and suspended in a $\mathrm{M} / 15 \mathrm{Na}-\mathrm{K}$ phosphate buffer ( $\mathrm{pH} \mathrm{7}$ ). It should be noted that, although this phosphate concentration was recorded as inhibiting the growth of cultures (Happold et.al. 1954), phosphate concentrations between $\mathrm{m} / 10$ and $\mathrm{M} / 100$ showed no effect with washed cell suspensions. Some attempts were made to prepare crushed cells and cell extracts using the Hughes press (Hughes, 1951) or by shaking with glass beads.

Estimations. All colorimetric and turbidimetric measurements were made with a Unicam D.G. Spectrophotometer.

Potassium thiocyanate solutions were standardized against silver nitrate. Ammonia was estimated, after removal of cells, by the addition of Nessler reagent. Sulphate was estimated turbidimetrically after removal of cells, by the addition of solid barium chloride and comparison with freshly prepared standards. Colorimetric estimations of sulphide were made by Pomeroy's method (Pomeroy, 1936). This method did not appear to be entirely satisfactory and the results obtained were regarded as semi-quantitative. Sodium sulphide and sodium sulphite solutions were standardized by the addition of excess standard iodine and back titration with sodium thiosulphate. Sodium cyanate solutions were prepared by weight, and the ammonia production on hydrolysis was taken as an indication of the purity of the sample. Tetrathionate and trithionate were prepared by the method of Kurtenacker \& Matejka (1930). Owing to the difficulty of preparing pure samples of tetrathionate, a second method was employed, namely the oxidation of thiosulphate by iodine.

Respiration experiments were made at $30^{\circ}$ by the usual manometric techniques. Carbon dioxide production from cyanate was determined by allowing the reaction to occur in the absence of $\mathrm{KOH}$ and then freeing the dissolved carbon dioxide by tipping in hydrochloride acid at the end of the reaction. Carbon dioxide production from thiocyanate was determined by the difference in gas volume change in the presence and absence of $\mathrm{KOH}$ 
$(0.2 \mathrm{ml} .10 \% \mathrm{KOH})$. Hydrochloric acid was tipped at the end of the reaction in flasks which contained no $\mathbf{K O H}$.

Owing to the rapid loss of $\mathrm{H}_{2} \mathrm{~S}$ from neutral sulphide solutions the following technique was adopted for the addition of sulphide to flasks. The cell suspension was placed in one side arm of a two side arm flask and un-neutralized sodium sulphide was added to the other. The main compartment contained phosphate buffer and sufficient hydrochloric acid to neutralize the sulphide. No KOH was present. The sulphide solution was the last addition made to the flasks which were immediately attached to the manometers and transferred to the bath. The manometer taps were closed within a few seconds and the equilibrium time was kept as short as possible. It was necessary to record the initial reading before tipping in the sulphide as there was a release of $\mathrm{H}_{2} \mathrm{~S}$ on neutralization.

In all cases where a molar ratio of gas produced or absorbed to substrate metabolized was determined, the gas volume change with different amounts of substrate was measured. The results were plotted and the ratio, mole gas : mole substrate, was calculated from the slope of the best straight line. The ratios of the products of reaction were similarly determined.

Anaerobic experiments were made in Thunberg tubes. The introduction of $\mathrm{KOH}$ through the side arm before sampling was used in an attempt to decrease loss of $\mathrm{H}_{2} \mathrm{~S}$ to the air.

\section{RESULTS}

The metabolism of thiocyanate can be divided into several steps which were as far as possible studied separately. The experimental results are, therefore, divided according to the step with which they are concerned.

\section{Hydrolysis of thiocyanate}

This step can be represented as : $\mathrm{KCNS}+\mathrm{H}_{2} \mathrm{O}=\mathrm{HCNO}+\mathrm{KSH}$, but a simple demonstration of this reaction was not achieved because any cyanate formed was further hydrolysed to carbon dioxide and ammonia. In anaerobic conditions approximately $50 \%$ of the theoretical amount of sulphide was obtained experimentally; experimental difficulties, which included inhibition of the reaction by sulphide, loss of sulphide from solution and precipitation of metal sulphides on the cells, probably prevented the demonstration of higher yields by this method. In manometer flasks production of sulphide was observed under aerobic conditions when whole cells were exposed to $100 \mu \mathrm{g}$. cetyl trimethylammonium bromide per ml. or when cell extracts were used. Crushed cells did not show a complete loss of oxidizing ability, as the extracts did, but the rate of oxidation was much decreased.

\section{The hydrolysis of cyanate}

This step may be represented as: $\mathrm{NaCNO}+2 \mathrm{H}_{2} \mathrm{O}=\mathrm{CO}_{2}+\mathrm{NH}_{3}+\mathrm{NaOH}$. Ammonia and carbon dioxide were produced from cyanate. Cyanate in acid solutions decomposes to give ammonia and carbon dioxide so that the need to introduce acid to release dissolved carbon dioxide after bacterial hydrolysis 
was a disadvantage. However, production of ammonia and some production of carbon dioxide was demonstrated without the addition of acid. Table 1 shows the production of ammonia and carbon dioxide from different amounts of sodium cyanate.

\section{Table 1. The hydrolysis of cyanate}

Washed suspensions of Thiobacillus thiocyanoxidans grown on thiocyanate and suspended in $\mathrm{M} / 15 \mathrm{~K} \mathrm{Na}$ phosphate buffer $\left(\mathrm{pH} 7\right.$ ) were shaken in manometer flasks in air at $30^{\circ}$, with different amounts of sodium cyanate in the same buffer; final volume of liquid $3 \mathrm{ml}$. Carbon dioxide was determined as total gas volume released after acidification; ammonia was estimated as described in the text.

The molar ratio NaCNO: $\mathrm{CO}_{2}: \mathrm{NH}_{3}$ estimated graphically (see text); the ratio for this experiment was $1: 1 \cdot 08: 1 \cdot 1$.

$\begin{array}{ccc}\begin{array}{c}\text { NaCNO } \\ \text { added }\end{array} & \begin{array}{c}\text { Carbon dioxide } \\ \text { produced } \\ (\mu \text { mole })\end{array} & \begin{array}{c}\text { Ammonia } \\ \text { produced } \\ (\mu \text { mole })\end{array} \\ 0 & \mathbf{3 \cdot 0} & \mathbf{2 \cdot 5} \\ 2 & \mathbf{3 \cdot 3} & \mathbf{3 \cdot 4} \\ 4 & \mathbf{5 \cdot 9} & \mathbf{6 \cdot 3} \\ 6 & \mathbf{8 \cdot 0} & \mathbf{8 \cdot 6} \\ 8 & \mathbf{9 \cdot 4} & 10 \cdot 7 \\ 10 & 11 \cdot 0 & 13 \cdot 1\end{array}$

The oxidation of sulphide

The theoretical equation for the oxidation of sulphide was:

$$
\mathrm{Na}_{2} \mathrm{~S}+2 \mathrm{O}_{2}=\mathrm{Na}_{2} \mathrm{SO}_{4} \text {. }
$$

The absorption of oxygen and the production of sulphate from oxidation of sulphide were determined by the methods described. Table 2 shows the result of one such experiment. The sulphide concentration could not be allowed to exceed $\mathrm{M} / 600 \mathrm{Na}_{2} \mathrm{~S}$; above this concentration there was inhibition by sulphide, and sulphur rather than sulphate was found. Owing to this inhibitory effect of sulphide it was not possible to compare satisfactorily the rates of oxidation of sulphide and thiocyanate. However, over a short time interval with a low concentration of sulphide a rate was observed which was equal to the rate of oxidation of thiocyanate by the same suspension.

\section{Table 2. The oxidation of sulphide}

Washed suspensions of $T$. thiocyanoxidans grown on thiocyanate and suspended in $\mathbf{m} / \mathbf{1 5}$ $\mathrm{K}$ Na phosphate buffer ( $\mathrm{pH} 7$ ) were shaken in manometer flasks, in air, at $30^{\circ}$, with different amounts of sodium sulphide. Special precautions were taken to prevent loss of sulphide during equilibration and sulphate was determined at the end of the reaction (see text).

The molar ratio: $\mathrm{Na}_{2} \mathrm{~S}: \mathrm{O}_{2}: \mathrm{SO}_{4}$ estimated graphically (see text) was $1: 1 \cdot 7: 1 \cdot 09$.

$\begin{array}{ccc}\begin{array}{c}\mathrm{Na}_{2} \mathrm{~S} \\ \text { added } \\ (\mu \text { mole })\end{array} & \begin{array}{c}\text { Oxygen } \\ \text { absorbed } \\ (\mu \text { mole })\end{array} & \begin{array}{c}\text { Sulphate } \\ \text { produced } \\ (\mu \text { mole })\end{array} \\ \mathbf{0 . 0} & \mathbf{0} & \mathbf{0} \\ 0 \cdot 81 & \mathbf{0 . 7} & \mathbf{1 . 2} \\ \mathbf{1 . 6 2} & \mathbf{1 . 9} & \mathbf{2 \cdot 0} \\ \mathbf{2} \cdot 43 & \mathbf{3 . 5} & \mathbf{2 \cdot 9} \\ \mathbf{3} \cdot \mathbf{2 4} & \mathbf{5 . 2} & \mathbf{3 \cdot 9} \\ \mathbf{4 . 0 5} & \mathbf{6 . 7} & \mathbf{4 . 3}\end{array}$




\section{The production of ammonia and sulphate from thiocyanate}

The equation which has been suggested for the oxidation of thiocyanate is:

$$
2 \mathrm{KCNS}+5 \mathrm{H}_{2} \mathrm{O}+3 \mathrm{O}_{2}=\mathrm{K}_{2} \mathrm{SO}_{4}+\left(\mathrm{NH}_{4}\right)_{2} \mathrm{SO}_{4}+\mathrm{CO}_{2}+\left(\mathrm{CH}_{2} \mathrm{O}\right) \text {. }
$$

Ammonia was estimated in the flask contents when all gas uptake had ceased. Table 3 shows the ammonia yields from the metabolism of different amounts of thiocyanate. The yields were similar with or without $\mathrm{KOH}$ in the centre well. There was, therefore, no measurable assimilation of nitrogen even when carbon dioxide was also available. Thus, although the necessary conditions of growth were present, there could have been little growth in the short duration of the experiments.

\section{Table 3. The metabolism of thiocyanate}

Washed suspensions of Thiobacillus thiocyanoxidans, grown on thiocyanate and suspended in $\mathrm{M} / 15 \mathrm{~K} \mathrm{Na}$ phosphate buffer ( $\mathrm{pH} 7$ ) were shaken in air at $30^{\circ}$, with different amounts of KCNS. One series had $0.2 \mathrm{ml}$. KOH $(10 \%)$ in the centre well; to the other $0.2 \mathrm{ml}$. dil. $\mathrm{HCl}$ was added at the end of the reaction. Oxygen uptakes were determined in the first series and carbon dioxide production was found by difference between the two. Ammonia and sulphate were determined at the end of the reaction. The molar ratio

$$
\mathrm{KCNS}: \mathrm{O}_{2}: \mathrm{CO}_{2}: \mathrm{SO}_{4}^{-}: \mathrm{NH}_{3}
$$

\begin{tabular}{|c|c|c|c|c|}
\hline $\begin{array}{c}\text { KCNS } \\
\text { added } \\
(\mu \text { mole })\end{array}$ & $\begin{array}{c}\mathrm{O}_{2} \\
\text { absorbed } \\
(\mu \text { mole })\end{array}$ & $\begin{array}{c}\mathrm{CO}_{\mathbf{2}} \\
\text { produced } \\
(\mu \text { mole })\end{array}$ & $\begin{array}{c}\mathrm{SO}_{4} \\
\text { produced } \\
(\mu \text { mole })\end{array}$ & $\begin{array}{c}\mathbf{N H}_{\mathbf{3}} \\
\text { produced } \\
(\mu \text { mole })\end{array}$ \\
\hline 0 & $0 \cdot 3$ & $2 \cdot 5$ & 0 & 0 \\
\hline 2 & 3.2 & $\mathbf{3} \cdot \mathbf{4}$ & & \\
\hline 4 & $6 \cdot 4$ & . & 4.3 & $4 \cdot 2$ \\
\hline 6 & & $5 \cdot 1$ & $6 \cdot 6$ & 6.2 \\
\hline 8 & 12.8 & 6.2 & 8.6 & 8.2 \\
\hline 10 & $15 \cdot 6$ & $7 \cdot 9$ & 10.2 & $9 \cdot 9$ \\
\hline
\end{tabular}

estimated graphically (see text) was $1: 1 \cdot 55: 0 \cdot 53: 1 \cdot 02: 1.03$.

Sulphate was estimated in the flask contents at the end of oxygen uptake by suspensions which had been supplied with varying amounts of thiocyanate. The results of one such experiment are shown in Table 3.

\section{Oxygen absorption for the oxidation of thiocyanate}

During the oxidation of thiocyanate, carbon dioxide was produced by the initial hydrolysis of thiocyanate. It is possible that the organisms may be able to utilize some of this carbon dioxide before it leaves the cell and is absorbed by the KOH present in the centre well of the flasks. According to the equations which were previously suggested for the oxidation of thiocyanate (Happold \& Key, 1934; Gleen, 1949) thiocyanate is oxidized with the uptake of 2 mole oxygen to one of thiocyanate. In Table 3 the ratio mole $\mathrm{O}_{2}$ : mole KCNS was found to be $1.55: 1$. In other experiments the molar ratios were: $1.58: 1$, $1.62: 1,1.52: 1,1.62: 1$ and $1.45: 1$. These results are discussed later. The plotted curve for oxygen uptake during the oxidation of thiocyanate showed a short initial lag, presumably because the first step was a hydrolysis. 


\section{The production of carbon dioxide from thiocyanate}

This measurement was necessarily made while oxidative reactions were taking place. From the autotrophic nature of the organism it was to be expected that some fixation of carbon dioxide would be found. The details of one experiment are given in Table 3 . The ratios, mole $\mathrm{O}_{2}$ : mole KCNS and mole $\mathrm{CO}_{2}$ : mole $\mathrm{KCNS}$ in this experiment were $1.55: 1$ and $0.53: 1$ respectively. In two other experiments the molar ratios $\mathrm{O}_{2}: \mathrm{KCNS}: \mathrm{CO}_{2}$ were $1 \cdot 62: 1: 0 \cdot 65$ and $1 \cdot 45: 1: 0 \cdot 58$.

\section{The oxidation of thiosulphate}

The possibility that thiosulphate is an intermediate in the oxidation of thiocyanate is discussed later. The oxidation of thiosulphate may be represented: $\mathrm{Na}_{2} \mathrm{~S}_{2} \mathrm{O}_{3}+\mathrm{H}_{2} \mathrm{O}+2 \mathrm{O}_{2}=\mathrm{Na}_{2} \mathrm{SO}_{4}+\mathrm{H}_{2} \mathrm{SO}_{4}$. Table 4 shows the oxygen absorption and sulphate production from different amounts of thiosulphate. These were in close agreement with the theoretical equation. The oxidation of thiosulphate was linear from the time of addition and the rate was usually equal to or greater than the rate of oxidation of equimolar amounts of thiocyanate.

\section{Table 4. The oxidation of thiosulphate}

Washed suspensions of Thiobacillus thiocyanoxidans grown on thiocyanate and suspended in $\mathrm{M} / 15 \mathrm{~K} \mathrm{Na}$ phosphate buffer $\left(\mathrm{pH} 7\right.$ ) were shaken in air at $30^{\circ}$, with different amounts of $\mathrm{Na}_{2} \mathrm{~S}_{2} \mathrm{O}_{3}$. KOH $(0.2 \mathrm{ml}$. of $10 \%)$ was present in the centre well of each flask. Sulphate was estimated in flask contents at end of reaction.

The molar ratio $\mathrm{Na}_{2} \mathrm{~S}_{2} \mathrm{O}_{3}: \mathrm{O}_{2}: \mathrm{SO}_{4}^{-}$was $1: 1 \cdot 94: 2 \cdot 10$.

$\begin{array}{ccc}\begin{array}{c}\mathrm{Na}_{2} \mathrm{~S}_{2} \mathrm{O}_{3} \\ \text { added }\end{array} & \begin{array}{c}\mathrm{O}_{2} \\ \text { absorbed } \\ (\mu \text { mole })\end{array} & \begin{array}{c}\mathrm{SO}_{4} \\ \text { produced } \\ (\mu \text { mole })\end{array} \\ 0 & 0 \cdot 54 & 0 \\ 4 & 8 \cdot 08 & 7 \cdot 9 \\ 6 & 11 \cdot 5 & 12 \cdot 7 \\ 8 & 15 \cdot 8 & 17 \cdot 1 \\ 10 & 20 \cdot 0 & 20 \cdot 6\end{array}$

\section{The fixation of carbon dioxide during thiocyanate oxidation}

The theory was considered, and is discussed later, that carbon dioxide entered into the oxidative metabolism of thiocyanate. Attempts were made to test the theory by seeking suitable inhibitors that might prevent the fixation of carbon dioxide; the theoretical uptake of oxygen, 2 mole $\mathrm{O}_{2}: 1$ mole $\mathrm{KCNS}$, might then be found. Three compounds which have been used for the inhibition of assimilation of carbon compounds by heterotrophs were tested. At a concentration known to inhibit heterotrophic assimilation sodium azide completely inhibited oxidation of thiocyanate. When the concentration was reduced from $\mathrm{M} / \mathbf{1 0 0}$ to $\mathrm{m} / \mathbf{1 0 0 0}$ the inhibition was still $85-90 \%$ and the compound was therefore unsuitable for use with this organism. 2:4-Dinitrophenol was employed at different concentrations; even when the concentration was higher than is commonly used for inhibiting heterotrophic assimilation, and the oxidation was partly inhibited, there was still no evidence that fixation of 
carbon dioxide was decreased. Iodoacetate was tested with similar results (see Table 5). The gas volumes quoted were calculated as oxygen uptakes but, when no KOH was present, the gas volume change represented the resultant of oxygen absorption, carbon dioxide fixation and carbon dioxide production. If inhibition of fixation had occurred the difference in gas volume change measured in the presence and absence of $\mathrm{KOH}$, would increase, due to the greater output of carbon dioxide. Iodoacetate has been described as inhibiting the fixation of carbon dioxide by Thiobacillus thiooxidans (Vogler, 1942).

Table 5. Oxidation of thiocyanate in the presence of 2:4-dinitrophenol and iodoacetate

Washed suspensions of Thiobacillus thiocyanoxidans, grown on thiocyanate and suspended in $\mathrm{M} / 15 \mathrm{~K} \mathrm{Na}$ phosphate buffer $\left(\mathrm{pH} 7\right.$ ), were shaken in air at $30^{\circ}$. The concentration of thiocyanate added to the flasks was constant but the inhibitor concentrations were different. At each concentration the reaction was observed in the presence and absence of $\mathbf{K O H}$ $(0.2 \mathrm{ml} ., 10 \%)$. The difference in gas volume taken up was calculated as if oxygen only were involved (see text).

\begin{tabular}{l}
\multicolumn{1}{c}{ Inhibitor } \\
$2: 4-D i n i t r o p h e n o l$ \\
$2: 4-D i n i t r o p h e n o l$ \\
$2: 4-D i n i t r o p h e n o l$ \\
2:4-Dinitrophenol \\
Iodoacetate \\
Iodoacetate \\
Iodoacetate
\end{tabular}

$\begin{array}{cc}\begin{array}{c}\text { Concentration } \\ (M)\end{array} & \begin{array}{c}\text { Difference } \\ \text { in gas uptake }\end{array} \\ 0 & (\mu 1 .) \\ 1 \times 10^{-4} & 80 \\ 5 \times 10^{-4} & 96 \\ 7 \cdot 5 \times 10^{-4} & 83 \\ 0 & 98 \\ 1 \times 10^{-4} & 106 \\ 1 \times 10^{-5} & 69 \\ & 128\end{array}$

\section{The simultaneous metabolism of thiosulphate and cyanate}

The theory that the simultaneous fixation of carbon dioxide is responsible for the low $\mathrm{O}_{2}$ : KCNS ratio observed in the presence of $\mathrm{KOH}$ is discussed later. It was considered that a similar low ratio might be observed during the oxidation of thiosulphate if carbon dioxide were similarly fixed. It was found that oxygen uptake during oxidation of thiosulphate was the same in the presence as in the absence of $\mathrm{KOH}$ and when ammonium sulphate was present as a nitrogen source. However, in metabolizing thiocyanate, the organism actively produced carbon dioxide and ammonia during the oxidation. The simultaneous metabolism of thiosulphate and cyanate was, therefore, examined in an attempt to make the experimental conditions more like those of thiocyanate metabolism. The metabolism of thiosulphate and cyanate was compared with that of each compound alone in an attempt to show whether carbon dioxide was fixed and whether the fixation of carbon dioxide resulted in a lower $\mathrm{O}_{2}: \mathrm{Na}_{2} \mathrm{~S}_{2} \mathrm{O}_{3}$ molar ratio.

The results of these experiments were not altogether satisfactory but appeared to indicate that the molar ratio for the oxidation of thiosulphate was unchanged by the simultaneous cyanate hydrolysis. The fixation of carbon dioxide from cyanate during oxidation of thiosulphate was not reproducible and the highest molar ratio $\mathrm{CO}_{2}$ fixed : $\mathrm{Na}_{2} \mathrm{~S}_{2} \mathrm{O}_{3}$ oxidized was $0 \cdot 2: 1$ which was only $50 \%$ of that fixed during thiocyanate oxidation. The results were, therefore, of little value in attempting to elucidate the role of carbon dioxide. 
The fixation of carbon dioxide from the gaseous phase after oxidation of thiosulphate was determined by releasing carbon dioxide in the closed system. Corrections were made for the gas which went into solution. Again the results were not reproducible. The maximum ratio $\mathrm{CO}_{2}$ fixed : $\mathrm{Na}_{2} \mathrm{~S}_{2} \mathrm{O}_{3}$ oxidized was 0.12 mole : 1 mole. This suggested that the fixation of carbon dioxide was even less efficient when it did not occur simultaneously with the oxidation of the sulphur compound.

\section{The influence of growth substrate on oxidation rates}

A comparison was made of the rates of oxidation of thiocyanate and thiosulphate by cells which had been grown on thiosulphate or on thiocyanate. As the suspensions from thiosulphate media contained a considerable amount of particulate sulphur which was not removed in washing the two suspensions could not be adjusted by turbidity for comparison. The suspensions were prepared making a rough allowance for the sulphur content, and total nitrogen values were determined in order to provide a basis of comparison. The nitrogen concentrations were $150 \mu \mathrm{g}$. N/ml. for the suspension grown on thiocyanate and $140 \mu \mathrm{g}$. $\mathrm{N} / \mathrm{ml}$. for the suspension grown with thiosulphate. Table 6 shows the $Q_{\mathrm{O}_{2}}(\mathrm{~N})$ values. The values quoted for thiocyanate and thiosulphate oxidation have been corrected for the endogenous respiration. The high 'endogenous respiration' of the cells grown on thiosulphate might have been due to the oxidation of sulphur. The organisms will grow on elementary sulphur (Happold et al. 1954), but oxidation of elementary sulphur has not been demonstrated in manometric experiments. The rate of oxidation of thiocyanate by cells grown on thiosulphate increased with time.

\section{Table 6. A comparison of the rates of thiocyanate and thiosulphate oxidation by cells grown on thiosulphate of thiocyanate}

Washed suspensions of Thiobacillus thiocyanoxidans, grown on thiocyanate or thiosulphate, and suspended in $\mathrm{M} / 15 \mathrm{~K} \mathrm{Na}$ phosphate buffer ( $\mathrm{pH} 7$ ) were shaken in air at $30^{\circ}$. $\mathrm{KOH}(0.2 \mathrm{ml} ., 10 \%)$ was present in all flasks. Values quoted for thiocyanate and thiosulphate oxidation have been corrected for the endogenous rate.

$\begin{array}{llc}\begin{array}{c}\text { Growth } \\ \text { substrate }\end{array} & \begin{array}{c}\text { Respiration } \\ \text { substrate }\end{array} & \mathrm{Q}_{\mathrm{O}_{2}}(\mathrm{~N}) \\ \mathrm{KCNS} & \text { None } & 10 \\ \mathrm{KCNS} & \mathrm{KCNS} & 1363 \\ \mathrm{KCNS} & \mathrm{Na}_{2} \mathrm{~S}_{2} \mathrm{O}_{3} & 983 \\ \mathrm{Na}_{2} \mathrm{~S}_{2} \mathrm{O}_{3} & \mathrm{None} & 121 \\ \mathrm{Na}_{2} \mathrm{~S}_{2} \mathrm{O}_{3} & \mathrm{KCNS} & 100 \\ \mathrm{Na}_{2} \mathrm{~S}_{2} \mathrm{O}_{3} & \mathrm{Na}_{2} \mathrm{~S}_{2} \mathrm{O}_{3} & 678\end{array}$

The oxidation of thioacetamide and thioacetate

Cells which had been grown on thiocyanate oxidized thioacetamide $\left(\mathrm{CH}_{3} . \mathrm{CS} . \mathrm{NH}_{2}\right)$ to sulphate but at a slower rate than thiocyanate. Table 7 shows the oxygen absorption and sulphate production with thioacetamide. A large endogenous respiration occurred in this experiment because a heavy cell suspension was employed. In order to determine whether the organism was directly metabolizing thioacetamide, a comparison was made between the 
anaerobic metabolism of thiocyanate and that of thioacetamide. No sulphide was produced from thioacetamide. It was also observed that the rate of oxidation of thioacetamide was not increased when cell suspensions of greater density were employed. Potassium thioacetate $\left(\mathrm{CH}_{3} . \mathbf{C S K}\right)$ was less stable in solution and sulphide was detectable within a short time of preparation. The rate of oxidation of thioacetate was comparable to the rate of oxidation of thiocyanate.

\section{Table 7. The oxidation of thioacetamide}

Washed suspensions of Thiobacillus thiocyanoxidans grown on thiocyanate and suspended in $\mathrm{M} / 15 \mathrm{KNa}$ phosphate buffer $(\mathrm{pH} 7)$ were shaken in manometer flasks in air at $30^{\circ}$, with different amounts of thioacetamide. KOH (0.2 ml., $10 \%)$ was present in all flasks. Sulphate was estimated in the flask contents at the end of the reaction.

The molar ratio, $\mathrm{CH}_{3} \mathrm{CSNH}_{2}: \mathrm{O}_{2}: \mathrm{SO}_{4}$ estimated graphically (see text) was $1: 2 \cdot 06: 0 \cdot 93$.

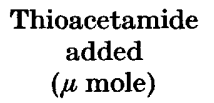

0

$1 \cdot 6$

$2 \cdot 4$

$\mathbf{3} \cdot 2$

4.0
Oxygen
absorbed
$(\mu$ mole $)$

$\mathbf{3} \cdot \mathbf{8 4}$

$7 \cdot 14$

$8 \cdot 93$

$10 \cdot 67$

$12 \cdot 01$

$\mathrm{SO}_{4}$
produced
$(\mu$ mole $)$
$\mathbf{0 \cdot 4 4}$
$\mathbf{1} \cdot 50$
$\mathbf{2 \cdot 0}$
$\mathbf{2 \cdot 9 7}$
$\mathbf{4} \cdot \mathbf{2 8}$

$4 \cdot 28$

The oxidation of other sulphur compounds, formaldehyde and formate

The following compounds were not oxidized: potassium dithionate, potassium trithionate, potassium sulphate, potassium pyrosulphate, thiourea, cysteine. The possibility that some oxidation occurred with sodium sulphite, sodium tetrathionate, potassium metabisulphite and sodium dithionite was not eliminated. The difficulty in interpreting results with these compounds was due to their instability and the small observed differences between the rate of oxygen uptake by living and heat-killed suspensions on these substrates.

In the equation which has been suggested for the metabolism of thiocyanate the fixed carbon appears as $\left(\mathrm{CH}_{2} \mathrm{O}\right)$. A test was made with chromotropic acid for formaldehyde after thiocyanate oxidation. It was thought that, if the later stages of autotrophic carbon fixation resembled those of heterotrophs, intermediates might accumulate in the presence of 2:4-dinitrophenol. No formaldehyde was found in these conditions. The reaction has not been carried out in the presence of a fixative for formaldehyde. Washed suspensions of Thiobacillus thiocyanoxidans oxidized formate.

\section{DISCUSSION}

Thiobacillus thiocyanoxidans hydrolyses thiocyanate to sulphide and it is reasonable to suppose that the other product of hydrolysis is cyanate, since this compound is hydrolysed by the organism to carbon dioxide and ammonia. The equations which represent these steps are:

$$
\begin{aligned}
& \mathrm{KCNS}+\mathrm{H}_{2} \mathrm{O}=\mathrm{KSH}+\mathrm{HCNO} ; \\
& \mathrm{HCNO}+\mathrm{H}_{2} \mathrm{O}=\mathrm{NH}_{3}+\mathrm{CO}_{2} .
\end{aligned}
$$


Sulphide was oxidized quantitatively to sulphate and the molar ratio $\mathrm{O}_{2}: \mathrm{Na}_{2} \mathrm{~S}$ found of $1 \cdot 7: 1$ approaches the ratio required by the equation: $\mathrm{Na}_{2} \mathrm{~S}+2 \mathrm{O}_{2}=\mathrm{Na}_{2} \mathrm{SO}_{4}$. The quantitative production of sulphate found indicated that the experimental precautions were successful in preventing loss of sulphide from the system, and the low oxygen ratios might be explained as the result of distillation of sulphide into the cell suspensions during equilibration.

The molar ratio for the oxidation of thioacetamide, $\mathrm{O}_{2}: \mathrm{CH}_{3} \mathrm{CSNH}_{2}=2 \cdot 06: 1$, may also supply evidence for the oxidation of sulphide. It is probable that the normal equilibrium in solution does not favour the production of sulphide, but that the constant removal of traces of sulphide by the organism produces a shift in the equilibrium. The organism did not split off sulphide from thioacetamide as it did in the case of thiocyanate. Since the rate determining step was the slow hydrolysis of thioacetamide, the rate of oxidation was not increased by increasing the cell concentration. The different rate of oxidation of thioacetate, which hydrolyses rapidly in solution, supported this theory. The oxidation of thioacetamide is, therefore, considered to show the quantitative oxidation of sulphide under conditions where the loss of sulphide was decreased to a minimum.

The ability of cells grown on thiocyanate to oxidize thiosulphate while cells grown on thiosulphate showed little ability to metabolize thiocyanate, suggested that thiosulphate might be an intermediate in thiocyanate oxidation, but this was not directly demonstrated. An alternative scheme for the oxidation of sulphide was through sulphite, but the rate of oxidation of sulphite in the presence of living cells was so little greater than the rate in the presence of killed cells that it appeared unlikely that sulphite was an intermediate. Similarly, no evidence was found for the oxidation of thiosulphate through polythionates. The following scheme is therefore suggested:

$$
\begin{aligned}
& \text { (1) } 2 \mathrm{KSH}+2 \mathrm{O}_{2}=\mathrm{K}_{2} \mathrm{~S}_{2} \mathrm{O}_{2}+2 \mathrm{OH}^{-} \\
& \text {(2) } \mathrm{K}_{2} \mathrm{~S}_{2} \mathrm{O}_{2}+2 \mathrm{OH}^{-}+\mathrm{H}_{2} \mathrm{O}=\mathrm{K}_{2} \mathrm{~S}_{2} \mathrm{O}_{3}+2 \mathrm{H}_{2} \mathrm{O} \text {, } \\
& \text { (3) } \mathrm{K}_{2} \mathrm{~S}_{2} \mathrm{O}_{3}+\mathrm{O}_{2}=\mathrm{K}_{2} \mathrm{~S}_{2} \mathrm{O}_{5} \\
& \text { (4) } \mathrm{K}_{2} \mathrm{~S}_{2} \mathrm{O}_{5}+\mathrm{O}_{2}=\mathrm{K}_{2} \mathrm{~S}_{2} \mathrm{O}_{7} \\
& \text { (5) } \mathrm{K}_{2} \mathrm{~S}_{2} \mathrm{O}_{7}+\mathrm{H}_{2} \mathrm{O}=\mathrm{K}_{2} \mathrm{SO}_{4}+\mathrm{H}_{2} \mathrm{SO}_{4} \text {. }
\end{aligned}
$$

Thiosulphurous acid, $\mathrm{H}_{2} \mathrm{~S}_{2} \mathrm{O}_{2}$, only exists as esters, and these on hydrolysis in the presence of alkali yield thiosulphate. It is possible that step 2 occurs spontaneously. Pyrosulphate does not exist in solution but goes to sulphate as indicated by step 5 . The compound $\mathrm{K}_{2} \mathrm{~S}_{2} \mathrm{O}_{5}$ does not exist as such in solution so that the uncertain results obtained on the addition of metabisulphite to cell suspensions could neither confirm nor disprove this theory. The overall reaction for this scheme was the theoretical equation for sulphide oxidation: $2 \mathrm{KSH}+4 \mathrm{O}_{2}=\mathrm{K}_{2} \mathrm{SO}_{4}+\mathrm{H}_{2} \mathrm{SO}_{4}$. The oxidation of thiosulphate followed the theoretical equation given previously. This scheme, although not proved, is in agreement with the experimental data.

It will be seen that the hydrolysis of thiocyanate and the oxidation of sulphide, excluding the process of carbon dioxide fixation, occur according to the 
equation proposed by Happold \& $\mathrm{Key}(1934): 2 \mathrm{KCNS}+4 \mathrm{H}_{2} \mathrm{O}+4 \mathrm{O}_{2}=\mathrm{K}_{2} \mathrm{SO}_{4}+$ $\left(\mathrm{NH}_{4}\right)_{2} \mathrm{SO}_{4}+2 \mathrm{CO}_{2}$. The amounts of ammonia and sulphate formed from thiocyanate were in agreement with this equation, but the oxygen absorption and carbon dioxide production were not. Since the production of the theoretical amount of sulphate was observed it appeared that some other compound was serving as source of oxygen, either directly or indirectly. In the system the possible sources of oxygen appeared to be carbon dioxide and water. It was thought that carbon dioxide was the most likely source since the fixation of carbon dioxide necessitates its reduction. If oxygen had been derived from water, hydrogen should have been produced; there did not appear to be any likely hydrogen acceptors present other than oxygen and carbon dioxide and the production of free hydrogen should have led to lower gas uptakes than were observed.

The difference between the theoretical amount of $\mathrm{CO}_{2}$ to be expected and that found experimentally was equivalent to the difference between the theoretical and observed $\mathrm{O}_{2}$ uptakes. It was possible to envisage the reaction of carbon dioxide with a sulphur compound at some stage, but the following mechanism appeared to be more satisfactory: $\mathrm{CO}_{2}+\mathrm{H}_{2} \mathrm{O}=\mathrm{CH}_{2} \mathrm{O}+\mathrm{O}_{2}$. The production of one molecule of oxygen for each molecule of carbon dioxide fixed was sufficient to explain the apparent deficiency in the oxygen absorbed. The combination of this equation with the equations for the hydrolysis of KCNS and the oxidation of sulphide yields the overall equation which was suggested by the experimental results, i.e. $2 \mathrm{KCNS}+5 \mathrm{H}_{2} \mathrm{O}+3 \mathrm{O}_{2}=\mathrm{K}_{2} \mathrm{SO}_{4}+$ $\left(\mathrm{NH}_{4}\right)_{2} \mathrm{SO}_{4}+\mathrm{CO}_{2}+\left(\mathrm{CH}_{2} \mathrm{O}\right)$.

I wish to acknowledge helpful criticism and advice from Prof. F. C. Happold and Mr S. Dagley of the Biochemistry Department. I have also to thank Mr Huybers of Brisbane, Australia, for financial support during the first 6 months of this work and to the Gas Research Council for the later period.

\section{REFERENCES}

Gleen, H. (1949). The metabolism of thiocyanate oxidising bacteria in soil. 1st Int. Congr. Biochem. 514.

HAPpold, F. C. \& KEy, A. (1934). Institution of Gas Engineers. 4th Report of the Liquor Effluents and Ammonia Subcommittee.

Happold, F. C. \& KEy, A. (1937). The bacterial purification of gas works liquors. 11. The biological oxidation of ammonium thiocyanate. Biochem. J. 31, 1323.

Happold, F. C., Johnstone, K. I. \& Rogers, H. J. (1952). An examination of Bacterium thiocyanoxidans. Nature, Lond. 169, 332.

Happold, F. C., Johnstone, K. I., Rogers, H. J. \& Youatt, J. B. (1954). Isolation and characteristics of an organism oxidizing thiocyanate. J. gen. Microbiol. 10, 261.

Hughes, D. E. (1951). A press for disrupting bacteria and other micro-organisms. Brit. J. exp. Path. 32, 97.

Kurtenacker, A. \& MateJka, J. (1930). Über die Darstellung von Tetra- und Trithionat aus Thiosulfat und Schwefliger Säure. Z. anorg. Chem. 193, 367.

Pomeroy, R. (1936). An improved method for the estimation of sulphides. Waterwks \& Sewerage, 83, 279.

Vogler, K. G. (1942). Studies in the metabolism of autotrophic bacteria. II. The nature of the chemosynthetic reaction. J. gen. Physiol. 26, 89.

(Received 9 January 1954) 